\title{
Association between Troponin I and Mortality in COVID-19 Patients: Meta-Analysis Study
}

\author{
Hesthi Krisnawati'), Yulia Lanti Retno Dewi²), Bhisma Murti') \\ ${ }^{1)}$ Masters Program in Public Health, Universitas Sebelas Maret \\ 2)Faculty of Medicine, Universitas Sebelas Maret
}

\section{ABSTRACT}

Background: COVID-19 is a new disease caused by the severe acute respiratory syndrome coronavirus 2 (SARS-CoV-2). COVID-19 became a pandemic disease that killed 4 million people for almost 2 years. COVID-19 patients with comorbidities or risk factors are more prone to have a worse prognosis, one of which is a heart disease which can be checked through troponin I values. This study aims to determine the relationship between troponin I levels and mortality in patients with COVID-19.

Subjects and Method: This study includes a meta-analysis by searching for articles from databases such as Science Direct, Springer, Google Scholar, and PubMed using the keywords: troponin I, cohort, fatality, cardiac biomarker, death, coronavirus, COVID-19 mortality, and COVID-19. Ten accredited articles published between 2019-2021 were included for meta-analysis. The subjects of this study were 10,499 COVID-19 patients. The intervention in this study was high troponin I levels, while the comparison was normal troponin I levels. The outcome of this study is mortality in COVID-19 patients. Data processing using Review Manager software version 5.3 for the relationship between troponin I levels and mortality in COVID-19 patients.

Results: From a meta-analysis of 10 primary research articles in China, Spain, New York (United States), France, Turkey, and Philadelphia (United States) showed an association between high troponin I levels and an increased risk of mortality in COVID-19 patients $(\mathrm{aOR}=3.07$; 95\% CI= 1.68 to $5.61 ; \mathrm{p}<0.003)$.

Conclusion: High troponin I levels increase the risk of mortality in COVID-19 patients.

Keywords: troponin I, heart disease, mortality, COVID-19.

\section{Correspondence:}

Hesthi Krisnawati. Masters Program in Public Health, Universitas Sebelas Maret. Jl. Ir. Sutami 36A, Surakarta 57126, Central Java. Email: hesthikrisna86@gmail.com. Mobile: +6285278067840 .

\section{Cite this as:}

Krisnawati H, Dewi YLR, Murti B (2021). Association between Troponin I and Mortality in COVID-19 Patients: Meta-Analysis Study. Indones J Med. 06(03): 347-353. https://doi.org/10.26911/theijmed.2021.06.03.12.

c) (i) (2) Indonesian Journal of Medicine is licensed under a Creative Commons

EY NG SA Attribution-Non Commercial-Share Alike 4.0 International License.

\section{BACKGROUND}

COVID-19 is a new disease caused by the severe acute respiratory syndrome coronavirus 2 (SARS-CoV-2), also called coronavirus (Pane, 2021a). This coronavirus infection was first discovered in Wuhan, China, in December 2019. Also, on January 30, 2020, WHO sounded the public health emergency alarm that became the concern of the whole world, namely the Public Health Emergency of International Concern (PHEIC). This virus is contagious quickly; in just a few months, it has spread to almost all countries, including Indonesia (Pane, 2021b). 
As of September 24, 2021, as many as 219 million people in the world have confirmed COVID-19, with more than 4 million people have died from this new pandemic disease. Meanwhile, in Indonesia alone, 4 million people were found to be positive for COVID-19, with 140 thousand of them declared dead (Levani et al., 2021; WHO, 2021).

COVID-19 patients with comorbidities or risk factors are more prone to poorer prognoses. The results of Satria's research found that COVID-19 patients who died with risk factors based on comorbidities, the heart of 12 patients observed was seven people (58.33\%) died (OR= 4.32, $\mathrm{p}=0.009)$ (Satria, 2020).

One of the heart diseases that cause high mortality is coronary heart disease, by considering troponin I examination as an indicator of initial diagnosis. Troponin I showed highly specific results against myocardial tissue damage. Thus, high troponin levels in COVID-19 patients have a close relationship with the death of COVID-19 patients with comorbid heart disease.

Researchers will analyze the metaanalysis of ten empirical literature to see the relationship between troponin I levels and the risk of mortality in patients with COVID-19.

\section{SUBJECTS AND METHOD}

\section{Study Design}

This study uses primary data collection by conducting searches on journal articles on the internet, by utilizing accredited journal facilities such as Google Scholar, Springer Link, Science Direct, and PubMed. Researchers used the keywords "troponin I" AND "mortality COVID-19", "troponin I" AND "mortality Coronavirus", "troponin I" AND "COVID-19", "troponin I" AND "COVID-19" AND "cohort", "troponin I" AND "fatality COVID-19", "troponin I"
AND "fatality Coronavirus", "troponin I" AND "death COVID-19", "troponin I" AND "death Coronavirus", "cardiac biomarker" AND "mortality COVID-19", "cardiac biomarker" AND "mortality Coronavirus", "cardiac biomarker" AND "fatality COVID19", "cardiac biomarker" AND "fatality Coronavirus", "cardiac biomarker" AND "death COVID-19", "cardiac biomarker" AND "death Coronavirus".

\section{Inclusion Criteria}

The inclusion criteria for articles that can be reviewed are full-paper articles with cohort study research methods, both prospective and retrospective.

Selected articles presented the final adjusted odds ratio (aOR) results, articles that analyze data in multivariate form, articles that discussed troponin I levels and mortality in patients with COVID-19.

\section{Exclusion Criteria}

The articles using bivariate analysis with crude OR, mean differences, descriptive studies, and meta-analyses or systematic reviews were excluded.

\section{Operational Definition of Variable}

The search for articles was carried out by considering the PICO model's eligibility criteria. The population in this study were patients who were declared to have COVID19 (Murti, 2018).

Troponin I is a type of cardiac enzyme that is sensitive and specific to damage to the heart muscle. Here, the respondent determines whether the troponin I value is normal or high.

COVID-19 patient mortality here is determined by the death status of patients diagnosed with COVID-19.

\section{Instruments}

The stages of this research followed the PRISMA flow diagram (Figure 1). The assessment of the quality of research articles was used the Critical Appraisal Checklist for Cohort Study by The Joanna Briggs 
Institute (JBI).

\section{Data Analysis}

After these criteria were met, the researchers processed the data using the Review Manager software version 5.3 to determine the correlation between troponin I level variables and mortality in COVID-19 patients. In addition, researchers also limit the journal articles that used to be publications between 2019-2021 or since COVID-19 was discovered.

\section{RESULTS}

The characteristics of this meta-analysis research are described in Table 1.

\section{A. Forest Plot}

The interpretation of the results of a metaanalysis study of the relationship between troponin I levels and mortality of COVID-19 patients can be seen in the Figure 2 forest plot. Based on the results of the analysis in the figure, it can be seen that 9 out of 10 articles reported that high troponin I levels in COVID-19 patients could affect the incidence of mortality. There was high heterogeneity between the primary studies $\left(\mathrm{I}^{2}=\right.$ 97\%; p<0.001), so the random-effects model was used in this study. In data analysis in the forest plot, high troponin I levels could increase the mortality of COVID-19 patients by 3.07 times compared to COVID19 patients with normal troponin $\mathrm{I}(\mathrm{aOR}=$ 3.07; $95 \% \mathrm{CI}=1.68$ to $5.61 ; \mathrm{p}<0.003)$.

\section{B. Funnel Plot}

Figure 3 showed that there is a publication bias where the distribution of plots between the right and left of the graph is asymmetrical, and the number of right and left plots is not the same, i.e. there are three plots on the left and five plots on the right, and two plots on the middle line.

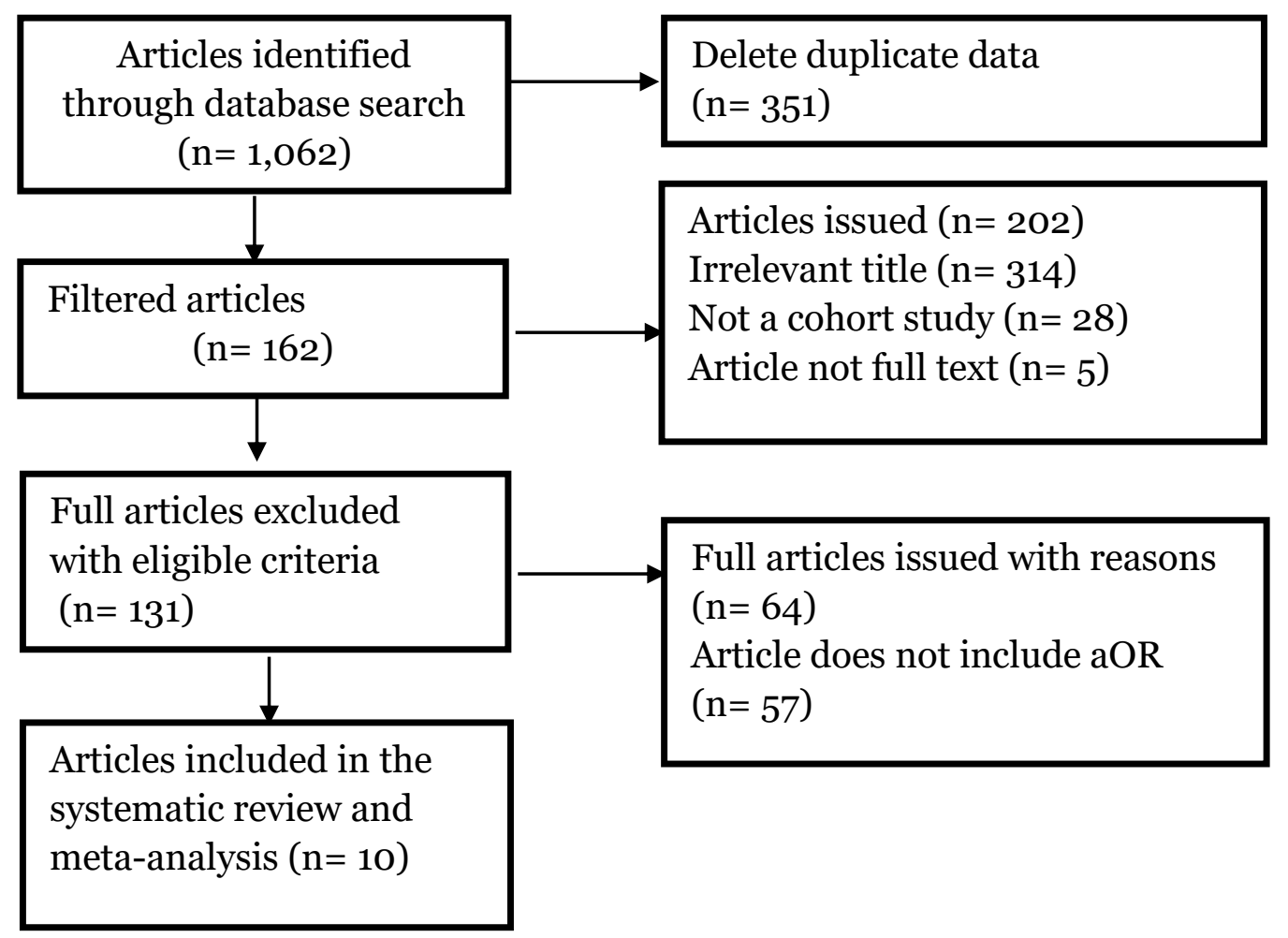

Figure 1. PRISMA Flow Diagram 
Table 1. Description of the source of the relationship between troponin I levels and mortality of COVID-19 patients

\begin{tabular}{|c|c|c|c|c|c|c|c|c|}
\hline $\begin{array}{c}\text { Author } \\
\text { (Year) }\end{array}$ & Title & Country & $\begin{array}{c}\text { Study } \\
\text { Design }\end{array}$ & $\begin{array}{c}\text { Sample } \\
\text { Size }\end{array}$ & $\begin{array}{c}\text { Population } \\
\text { (P) }\end{array}$ & $\begin{array}{l}\text { Intervention } \\
\text { (I) }\end{array}$ & Comparison (C) & $\begin{array}{c}\text { Outcome } \\
\text { (O) }\end{array}$ \\
\hline $\begin{array}{l}\text { Nie et al. } \\
\text { (2020) }\end{array}$ & $\begin{array}{l}\text { Cardiac troponin I is an independent } \\
\text { predictor for mortality in hospitalized } \\
\text { patients with COVID-19 }\end{array}$ & China & $\begin{array}{l}\text { Retrospective } \\
\text { cohort study }\end{array}$ & 311 & $\begin{array}{l}\text { COVID-19 } \\
\text { patient }\end{array}$ & High Troponin I & Normal Troponin I & Mortality \\
\hline $\begin{array}{l}\text { Romualdo et } \\
\text { al. (2021) }\end{array}$ & $\begin{array}{l}\text { Cardiac troponin and COVID-19 severity: } \\
\text { Results from BIOCOVID study } \\
\text { Troponin and other biomarker levels and }\end{array}$ & Spain & $\begin{array}{l}\text { Retrospective } \\
\text { cohort study }\end{array}$ & 1,280 & $\begin{array}{l}\text { COVID-19 } \\
\text { patient }\end{array}$ & High Troponin I & Normal Troponin I & Mortality \\
\hline $\begin{array}{l}\text { Manocha et } \\
\text { al. (2020) }\end{array}$ & $\begin{array}{l}\text { outcomes among patients hospitalized with } \\
\text { COVID-19: Derivation and validation of the } \\
\text { HA2T2 COVID-19 mortality risk score }\end{array}$ & $\begin{array}{l}\text { New York, } \\
\text { USA }\end{array}$ & $\begin{array}{l}\text { Prospective } \\
\text { cohort study }\end{array}$ & 180 & $\begin{array}{l}\text { COVID-19 } \\
\text { patient }\end{array}$ & High Troponin I & Normal Troponin I & Mortality \\
\hline $\begin{array}{l}\text { Cordeanu et } \\
\text { al. (2020) }\end{array}$ & $\begin{array}{l}\text { Prognostic value of troponin elevation in } \\
\text { COVID-19 hospitalized patients } \\
\text { Assessment of the relationship between }\end{array}$ & France & $\begin{array}{l}\text { Retrospective } \\
\text { cohort study }\end{array}$ & 375 & $\begin{array}{l}\text { COVID-19 } \\
\text { patient }\end{array}$ & High Troponin I & Normal Troponin I & Mortality \\
\hline $\begin{array}{l}\text { Ozyilmaz et } \\
\text { al. (2020) }\end{array}$ & $\begin{array}{l}\text { mortality and troponin I levels in } \\
\text { hospitalized patients with the novel } \\
\text { coronavirus (COVID-19) }\end{array}$ & Turkey & $\begin{array}{l}\text { Retrospective } \\
\text { cohort study }\end{array}$ & 105 & $\begin{array}{l}\text { COVID-19 } \\
\text { patient }\end{array}$ & High Troponin I & Normal Troponin I & Mortality \\
\hline $\begin{array}{l}\text { Chen et al. } \\
(2020)\end{array}$ & $\begin{array}{l}\text { Reduced cardiac function is associated with } \\
\text { cardiac injury and mortality risk in } \\
\text { hospitalized COVID-19 patients }\end{array}$ & $\begin{array}{l}\text { New York, } \\
\text { USA }\end{array}$ & $\begin{array}{l}\text { Retrospective } \\
\text { cohort study }\end{array}$ & 143 & $\begin{array}{l}\text { COVID-19 } \\
\text { patient }\end{array}$ & High Troponin I & Normal Troponin I & Mortality \\
\hline $\begin{array}{l}\text { Majure et al. } \\
(2020)\end{array}$ & $\begin{array}{l}\text { Usefulness of elevated troponin to predict } \\
\text { death in patients with COVID-19 and } \\
\text { myocardial injury }\end{array}$ & $\begin{array}{l}\text { New York, } \\
\text { USA }\end{array}$ & $\begin{array}{l}\text { Retrospective } \\
\text { cohort study }\end{array}$ & 6,247 & $\begin{array}{l}\text { COVID-19 } \\
\text { patient }\end{array}$ & High Troponin I & Normal Troponin I & Mortality \\
\hline $\begin{array}{l}\text { Chen et al. } \\
\text { (2021) }\end{array}$ & $\begin{array}{l}\text { Cardiac troponin I association with critical } \\
\text { illness and death risk in } 726 \text { seriously ill } \\
\text { COVID-19 patients: A retrospective cohort } \\
\text { study }\end{array}$ & China & $\begin{array}{l}\text { Retrospective } \\
\text { cohort study }\end{array}$ & 726 & $\begin{array}{l}\text { COVID-19 } \\
\text { patient }\end{array}$ & High Troponin I & Normal Troponin I & Mortality \\
\hline $\begin{array}{l}\text { Cetinkal et } \\
\text { al. (2020) }\end{array}$ & $\begin{array}{l}\text { Assessment of the modified CHA2DS2VASc } \\
\text { risk score in predicting mortality in } \\
\text { patients hospitalized with COVID-19 }\end{array}$ & Turkey & $\begin{array}{l}\text { Retrospective } \\
\text { cohort study }\end{array}$ & 717 & $\begin{array}{l}\text { COVID-19 } \\
\text { patient }\end{array}$ & High Troponin I & Normal Troponin I & Mortality \\
\hline $\begin{array}{l}\text { Woo et al. } \\
(2021)\end{array}$ & $\begin{array}{l}\text { Development and validation of a web-based } \\
\text { severe COVID-19 risk prediction model }\end{array}$ & $\begin{array}{l}\text { Philadelph } \\
\text { ia, USA }\end{array}$ & $\begin{array}{l}\text { Retrospective } \\
\text { cohort study }\end{array}$ & 415 & $\begin{array}{l}\text { COVID-19 } \\
\text { patient }\end{array}$ & High Troponin I & Normal Troponin I & Mortality \\
\hline
\end{tabular}


Krisnawati et al./ Troponin I and Mortality in COVID-19 Patients

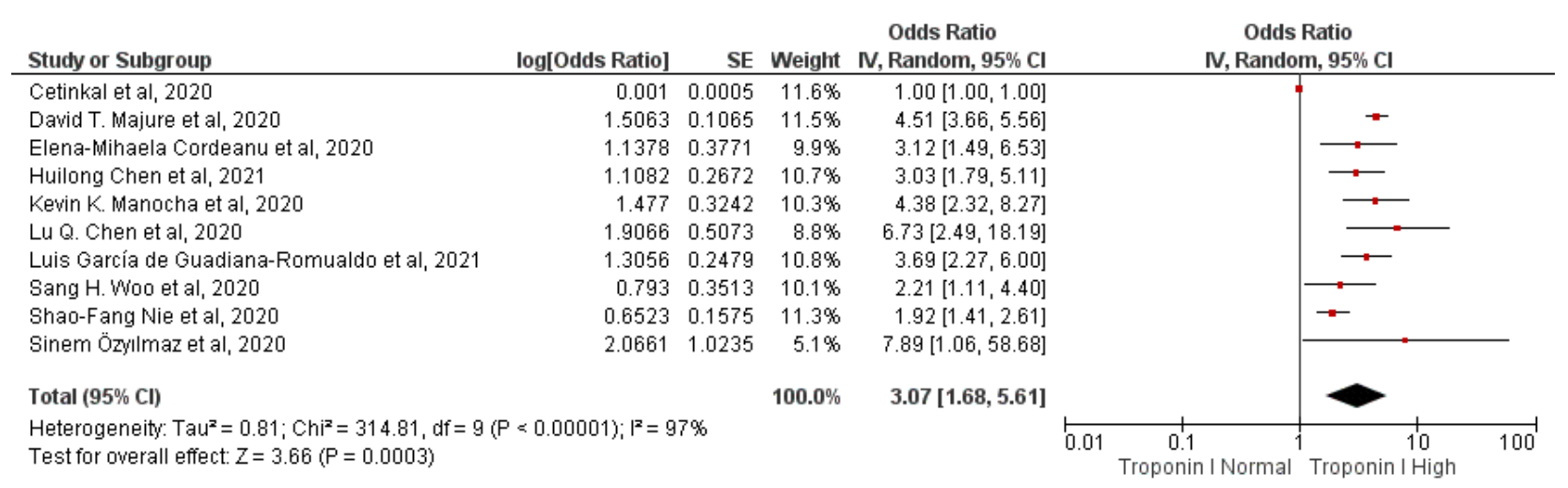

Figure 2. Forest Plot of The Relationship Between Troponin I Levels and Mortality in COVID-19 Patients

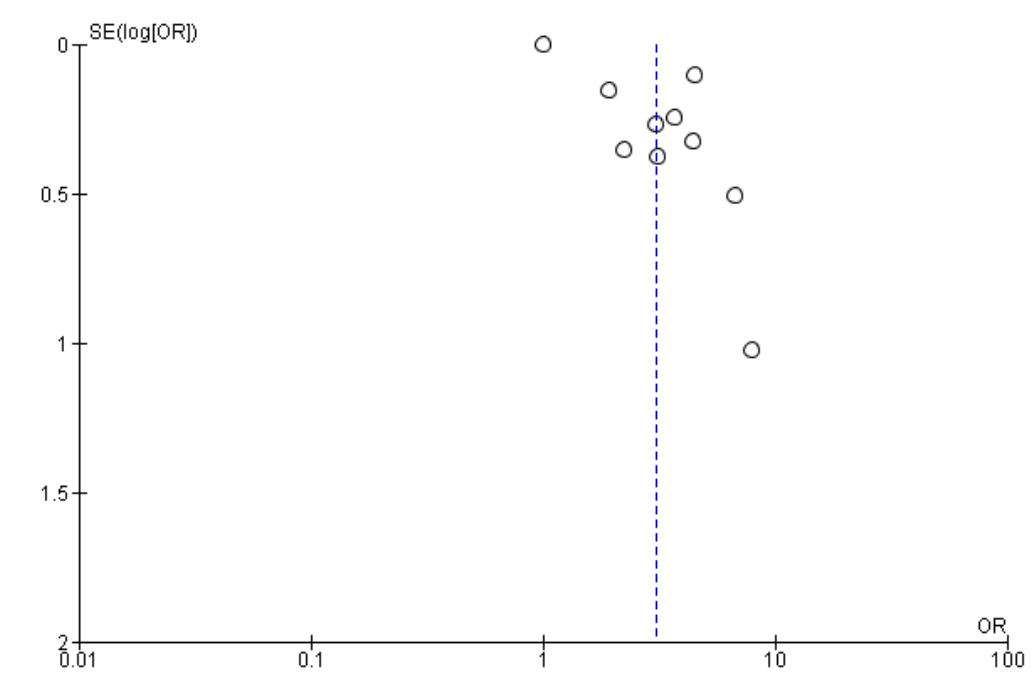

Figure 3. Funnel Plot of The Relationship between Troponin I Levels and Mortality in COVID-19 Patients

\section{DISCUSSION}

From this study, it can be seen that troponin I levels can increase the risk of mortality in COVID-19 patients $(\mathrm{aOR}=3.07)$ or COVID-19 patients with high troponin I have a mortality risk of 3.07 times compared to COVID-19 patients with normal troponin I. These results are in accordance with the research by Muhammad et al. (2020) who studied 200 adult patients who were hospitalized at Howard University, United States.

This study found that COVID-19 patients with high troponin I had 1.92 times the risk of mortality than COVID-19 patients with normal troponin I. They also identified other independent factors of both demographics and baseline comorbidities, such as age 65 years, inflammatory biomarkers (CRP, ferritin, interleukin-6, PCT), coagulation markers (D-dimer), acute organ damage, blood urea nitrogen (BUN), creatinine, lactate dehydrogenase (LDH). It is hoped that this biomarker examination can help doctors to identify patients who are at high risk for clinical deterioration.

$\mathrm{Du}$ et al. (2020) also conducted a similar study and found a fairly high relationship between troponin I levels and mortality in patients with COVID-19. They found that COVID-19 patients with high troponin I levels were 4.07 times more likely to experience mortality than COVID19 patients with normal troponin I levels. 
This result is higher than the findings of this study, which is 3.07 times.

Harmouch et al. (2021) found that there was a 1.48 times higher risk of mortality in COVID-19 patients with high troponin I levels than patients with normal troponin I levels. This research was conducted in St. Luke, Pennsylvania, United States from March 1, 2020 to April 15, 2020 in 563 patients hospitalized at this hospital.

The readiness of an area to face the COVID-19 pandemic also affects the development of COVID-19 in its region. Harmouch et al. (2021) conducted a study in the Pennsylvania state, where lockdowns and restrictions on activities have been carried out in business areas that are not providers of primary or essential needs. It is known that the results of this study showed that troponin I has a lower effect on mortality in patients with COVID-19 than in the New York area affected by COVID-19 from China earlier than any other state in the United States.

\section{AUTHOR CONTRIBUTION}

Hesthi Krisnawati is the lead researcher who conducted topic selection, search, and data collection. Yulia Lanti Retno Dewi and Bhisma Murti analyzed data and reviewed research documents.

\section{CONFLICT OF INTEREST}

There is no conflict of interest in this study.

\section{FUNDING AND SPONSORSHIP}

This study is self-funded.

\section{ACKNOWLEDGEMENT}

Thanks to Google Scholar, Springer Link, Science Direct, and PubMed databases.

\section{REFERENCE}

Cetinkal G, Kocas BB, Ser OS, Kilci H, Keskin K, Ozcan SN, Verdi Y, et al.
(2020). Assessment of the modified cha2ds2vasc risk score in predicting mortality in patients hospitalized with COVID-19. Am. J. Cardiol. 1-7. https://doi.org/10.1016/j.amjcard.2020.08. 040.

Chen H, Li X, Marmar T, Xu Q, Tu J, Li T, Han J, et al. (2021). Cardiac troponin i association with critical illness and death risk in 726 seriously ill COVID19 patients: a retrospective cohort study. Int. j. med. sci. res. 18(6): 14741483.https://doi.org/10.7150/ijms.536-41.

Chen LQ, Burdowski J, Marfatia R, Weber J, Gliganic K, Diaz N, Ramjattan N, et al. (2020). Reduced cardiac function is associated with cardiac injury and mortality risk in hospitalized COVID19 Patients. Clin. Cardiol. 43(12): 1547-1554.https://doi.org/10.1002/clc.23479.

Cordeanu EM, Duthil N, Severac F, Lambach H, Tousch J, Jambert L, Mirea C, et al. (2020). Prognostic value of troponin elevation in COVID-19 hospitalized patients. J Clin Med. 9(12): 4078.https://doi.org/10.3390/jcm9124078.

Du R, Liang L, Yang C, Wang W, Cao T, Li M, Guo G, et al. (2020). Predictors of mortality for patients with COVID-19 pneumonia caused by SARS-CoV-2: a prospective cohort study. Eur. Respir. J. 55:1-8. https://doi.org/10.1183/13993003.00524-2020.

Guadiana LG, Morell RD, Rodríguez GO, Indiano CM, María A, Padilla L, Miquel J, et al. (2021). Cardiac troponin and COVID-19 severity: results from biocovid study. Eur J Clin Invest. 112. https://doi.org/10.1111/eci.13532.

Harmouch F, Shah K, Hippen JT, Kumar A, Goel $H$ (2021). Is it all in the heart? Myocardial injury as major predictor 
of mortality among hospitalized COVID-19 patients. J. Med. Virol. 93: 973-982.https://doi.org/o.1002/jmv.26347.

Levani Y, Prastya AD, Mawaddatunnadila S, Wuhan K, Huebei P (2019). Coronavirus Disease 2019 (COVID-19): patogenesis, manifestasi klinis dan pilihan terapi. jurnal kedokteran dan kesehatan. 17(1): 44-57. https://doi.org/10.24853/jkk.17.1.44-57.

Majure DT, Gruberg L, Saba SG, Kvasnovsky C, Hirsch JS, Jauhar R (2021). Usefulness of elevated troponin to predict death in patients with COVID19 and myocardial injury. Am J Cardiovasc. 138: 100-106. https://doi.org/10.1016/j.amjcard.2020.09.060.

Manocha KK, Kirzner J, Ying X, Yeo I, Peltzer B, Ang B, Li HA, et al. (2020). Troponin and other biomarker levels and outcomes among patients hospitalized with COVID-19: derivation and validation of the ha2t2 COVID-19 mortality risk score. J. Am. Heart Assoc. 1-12. https://doi.org/10.1161/JAHA.120.018477.

Muhammad R, Ogunti R, Ahmed B, Munawar M, Donaldson S, Sumon M, Kibreab A, et al. (2020). Clinical characteristics and predictors of mortality in minority patients hospitalized with COVID-19 infection. J. Racial and Ethn Health Disparities. https://doi.org/10.1007/s40615-020-00961-x.

Murti B (2018). Prinsip dan Metode Riset Epidemiologi. Karanganyar: Bintang Fajar Offset.

Nie SF, Yu M, Xie T, Yang F, Wang HB, Wang ZH, Li M, et al. (2020). Cardiac troponin $\mathrm{i}$ is an independent predictor for mortality in hospitalized patients with COVID-19. Circ. 142(6): 608-
610. https://doi.org/10.1161/-CIRCULATIONAHA.120.048789.

Ozyilmaz S, Alis EE, Ermis E, Allahverdiyev S, Ucar H. (2020). Assessment of the relationship between mortality and troponin I levels in hospitalized patients with the novel coronavirus (COVID-19). Medicina. 56(693):1-12. https://doi.org/10.339o/medicina561 20693.

Pane MDC (2021a). COVID-19. Retrieved from dari Alodokter, 23 Juli 2021 website: https://www.alodokter.com/COVID-19.

Pane MDC (2021b). Virus Corona. Retrieved from Alodokter, 23 Juli 2021 website: https://www.alodokter.com/virus-corona.

Satria RMA, Tutupoho RP, Chalidyanto D. (2020). Analisis faktor risiko kematian dengan penyakit komorbid COVID19. Jurnal Keperawatan Silampari. 4: 48-55. https://doi.org/10.31539/jks.v4i1.1587.

The Joanna Briggs Institute (2017). Critical Appraisal tools for use in JBI Systematic Reviews Checklist for Cohort Studies.http://joannabriggs.org/research/critical-appraisal-tools.html.

WHO (2021). WHO: Coronavirus (COVID19) Disease Dashboard. Retrieved from https://covid19.who.int/.

Woo SH, Rios-Diaz AJ, Kubey AA, CheneyPeters DR, Ackermann LL, Chalikonda DM, Venkataraman $\mathrm{CM}$, et al. (2021). Development and validation of a web-based severe COVID-19 risk prediction model. Am. J. Med. Sci., 128. https://doi.org/10.1016/j.amjms.2021.04.001. 